\title{
Capsid Protein
}

National Cancer Institute

\section{Source}

National Cancer Institute. Capsid Protein. NCI Thesaurus. Code C16383.

The outer protective shell of a virus. The structure of the shell is icosahedral with either helical or complex symmetry. Capsid proteins surround and protect the viral nucleic acid core. 